\title{
Terminal organization of C-fiber afferents related with nociception or non-nociception
}

\author{
Yasuo Sugiura \\ Department of Functional Anatomy and Neuroscience, Nagoya University Graduate School \\ \& Faculty of Medicine, Nagoya, Japan
}

[Received 1 March 2002]

\begin{abstract}
The central projections of somatic, visceral and muscle unmyelinated C-fibers were examined in the guinea pig. The sensory modality of somatic $\mathrm{C}$-afferent fibers were identified by natural stimuli, pinch, noxious heat and cooling. The central projections of high threshold mechanoreceptor (HTM), mechanical-cold nociceptor (MCN), polymodal nociceptor (PN) and low threshold mechanoreceptor (LTM) were observed in the cervical and lumbar cord. All somatic unmyelinated C-fibers projected into the superficial dorsal horn (laminae I, II) with a densely concentrated termination. The terminal patterns and course of fiber trajectories differed in the two levels of the spinal cord, cervical or lumbar. The visceral C-afferent fibers mainly projected to the lamina I, $\mathrm{V}, \mathrm{X}$, and contralateral V, X in the thoracic cord. Muscle C-afferent fibers from the lateral gastrocunemius were labeled in the lumbar cord. Terminal branches were located in laminae I, II and III in the several lumbar segments. The number and size of terminal swellings were compared among these $\mathrm{C}$-afferent fibers to consider the nature of sensory processing.
\end{abstract}

Key words: unmyelinated fiber, central projection, somatic afferent, visceral afferent, muscle afferent

\section{侵害受容，非侵害受容を伝達する無髄神経（C 線維）の脊䯣終末機構 杉浦 康夫 \\ 〔名古屋大学大学院医学研究科機能形態学講座機能組織学分野〕}

\footnotetext{
余䯣一次求心性神経の中で無䯣神経 ( $\mathrm{C}$ 線維) は 主に痛覚や温度感覚に関係している。この無髄 $\mathrm{C}$ 線 維は，髄鞘がないことと線維が細いことから標識す ることが難しく，春髄での神経終末は有髄神経のよ うに詳細な研究はされていない，末梢神経はHRP
} あるいは WGA-HRPを各種器官に投与することによ
り, 中枢神経系での神経終末の形態や分布が明らか になっている 1,2,4,5,14 16,20,24,46,66,68,94,97). HRPを局 所投与する方法に加えて, 細胞内に注入することに より, 単一の神経の機能と終末分枝の形態学的解析 が可能になってきた.この細胞内注入法で有髄神経 を持つ神経細胞の形態学的特徽と単一神経細胞の機 
Table 1 Terminal domains and characteristics of each type of C-fibers

\begin{tabular}{|c|c|c|c|c|c|c|c|c|c|}
\hline $\begin{array}{l}\text { Sensory } \\
\text { modality of } \\
\text { receptive field }\end{array}$ & $\begin{array}{l}\text { Segmenta } \\
1 \text { level }\end{array}$ & $\begin{array}{l}\text { Cell } \\
\text { size } \\
(\mu \mathrm{m})\end{array}$ & $\begin{array}{l}\text { Con- } \\
\text { duction } \\
\text { velocity }\end{array}$ & $\begin{array}{l}\text { Receptive } \\
\text { fields }\end{array}$ & $\begin{array}{l}\text { fiber } \\
\text { course }\end{array}$ & $\begin{array}{l}\text { Rostrocaudal } \\
\text { extension } \\
(\mu \mathrm{m})\end{array}$ & $\begin{array}{l}\text { Dorsoventral } \\
\text { extension } \\
(\mu \mathrm{m})\end{array}$ & $\begin{array}{l}\text { Mediolateral } \\
\text { extension } \\
(\mu \mathrm{m})\end{array}$ & Laminae \\
\hline $\begin{array}{l}\text { High threshold } \\
\text { mechano- } \\
\text { receptor }\end{array}$ & C2 & $38 \times 16$ & 0.5 & $\begin{array}{l}\text { Centrum } \\
\text { of Pinna }\end{array}$ & $\begin{array}{l}\text { Lissauer's } \\
\text { tract }\end{array}$ & 280 & 100 & 150 & $\begin{array}{l}\text { IIo, part of } \\
\text { IIi }\end{array}$ \\
\hline $\begin{array}{l}\text { Polymodal } \\
\text { nociceptor }\end{array}$ & $\begin{array}{l}\mathrm{C} 2 \\
\mathrm{~L} 6\end{array}$ & $\begin{array}{l}30 \times 25 \\
42 \times 23\end{array}$ & $\begin{array}{l}0.5 \\
0.5\end{array}$ & $\begin{array}{l}\text { Anterior } \\
\text { of Pinna } \\
\text { III digit of } \\
\text { Lower leg }\end{array}$ & $\begin{array}{l}\text { Lissauer's } \\
\text { tract } \\
\text { Dorsal } \\
\text { funiclus }\end{array}$ & $\begin{array}{l}300 \\
150\end{array}$ & $\begin{array}{l}50 \\
150\end{array}$ & $\begin{array}{l}200 \\
200\end{array}$ & $\begin{array}{l}\text { IIi } \\
\text { I,IIo, } \\
\text { III.IV }\end{array}$ \\
\hline $\begin{array}{l}\text { Mechanical cold } \\
\text { nociceptor }\end{array}$ & $\begin{array}{l}\mathrm{C} 2 \\
\mathrm{~L} 6\end{array}$ & $\begin{array}{l}30 \times 25 \\
-\end{array}$ & $\begin{array}{l}0.5 \\
0.5\end{array}$ & $\begin{array}{l}\text { Anterior } \\
\text { of pinna } \\
\text { Backside } \\
\text { of thigh }\end{array}$ & $\begin{array}{l}\text { Lissauer's } \\
\text { tract } \\
\text { Lissauer's } \\
\text { tract }\end{array}$ & $\begin{array}{l}400 \\
450\end{array}$ & $\begin{array}{l}300 \\
100\end{array}$ & $\begin{array}{l}150 \\
150\end{array}$ & $\begin{array}{l}\text { I, part of } \\
\text { IIo } \\
\text { I, part of } \\
\text { IIo }\end{array}$ \\
\hline $\begin{array}{l}\text { low threshold } \\
\text { mechano- } \\
\text { receptor }\end{array}$ & $\begin{array}{l}\mathrm{C} 2 \\
\mathrm{C} 2\end{array}$ & $30 \times 20$ & $\begin{array}{l}1.5 \\
0.6\end{array}$ & $\begin{array}{l}\text { lateral of } \\
\text { pinna } \\
\text { Anterior } \\
\text { of pinna }\end{array}$ & $\begin{array}{l}\text { Lissuer's } \\
\text { tract } \\
\text { Lissauer's } \\
\text { tract }\end{array}$ & $\begin{array}{l}380 \\
300\end{array}$ & $\begin{array}{l}50 \\
50\end{array}$ & $\begin{array}{l}120 \\
100\end{array}$ & $\begin{array}{l}\text { IIo, part of } \\
\text { IIi } \\
\text { IIi-IIo }\end{array}$ \\
\hline
\end{tabular}

能を同時に得ることができた2,10,11 13,23,28,30,35 37, 47,82 84,86 88,95,96). さらにこの方法に免疫染色を加 え二重染色することにより，その終末の物質レベル までわかることになった ${ }^{47,52,73)}$.

春髄後角の中でも表層, 特に I 層 (marginal layer),

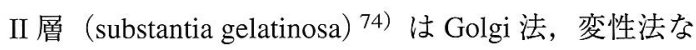
どを用い数多くの研究がなされ，細い有髄神経，無 髄神経など温痛覚を伝える一次求心性神経の終末部 位であることが明らかにされた7,17,19,44,58,69,70 72,76,96). 生理学的実験は無䯣一次求心性神経線維を持つ侵害 受容器, 機械的受容器が II 層の細胞を直接興奮させ ることを明らかにした ${ }^{41,46)}$.しかし形態学的な方 向からの多くのアプローチにも関わらず，侵害刺激 を伝える線維は二次ニューロンの細胞体に直接シナ プス接触する事実は示されなかった。無髄求心性神 経の脊髄での終末分布 90,93) の解析の結果からも二 次細胞の細胞体に一次求心性神経の終末が直接シナ プスを形成することはなく，一次求心性神経終末の 形成する中心終末に二次ニューロンの樹状突起が接 触することによって神経伝達が行われていることが 明らかにされてきた3,6,25,31,53,67,75,93).また一次神 経終末が放出するサブスタンス P に対する SPレセ プターの脊髄後角での分布も，直接的コンタタトを 示唆する同一部位での局在は見られていない34). そこで，この稿では痛みに関連する一次神経終末と りわけ各種の無䯣神経の終末の脊髄内分布の特幑を 述べ, 今後の痛覚の研究の基礎となるよう各種受容 器の脊髄内神経終末の形態を記載しておく.

\section{皮膚からの無䯑道一次求心性神経終末の脊檤内分布}

ここで記載した無䯣神経終末はいずれも雌モル モットを用いた実験結果である。ネンブタールによ る深麻酔下で後根神経節細胞から細胞内記録を行 い，末梢の電気刺激により伝導速度を測定し， $2 \mathrm{~m} /$ 秒以下の伝導速度を示すものを無髄神経であると同 定した. 神経細胞のトレーサーとして PHA-L を細 胞内に注入し PHA-Lに対する抗体で免疫染色し た ${ }^{29)}$. 末梢侵害受容器の感覚特性の同定はピンチ による機械的刺激, 冷却による寒冷刺激, 輻射熱に よる熱刺激などの自然刺激により誘導された細胞内 活動電位の記録によって確認した $8,9,40,45,48,85)$ (Table 1).

\section{1. 高閾值機械的受容器 (HTM)}

頚髄 2 番 (C2) 後根神経節で記録した, 強い機械 的刺激にのみ応ずる高間值機械的受容器 (HTM) は 大後頭神経を経て耳介中央部に受容野を持ってい た.中枢枝はC2 の高さで脊髄後根の内側より後角 表面に到達し後角 I, II 層を通過し, III, IV 層を通り ながら 2 〜 本に分岐する. その枝はいずれも後方 に 1 分節ほど走行し, 頚髄後角外側の I, II 層の境界 部で密な終末神経叢を作る.その終末神経叢はおよ そ吻尾方向に $280 \mu \mathrm{m}$, 背腹方向に $100 \mu \mathrm{m}$ であった (Fig. 1)。 HTM の脊髄内分枝は走行途中, 目立った 終末膨大を示さず, 終末神経叢を作るところでは大 きさが数ミクロンにも及ぶ多数の終末膨大を形成す る. 


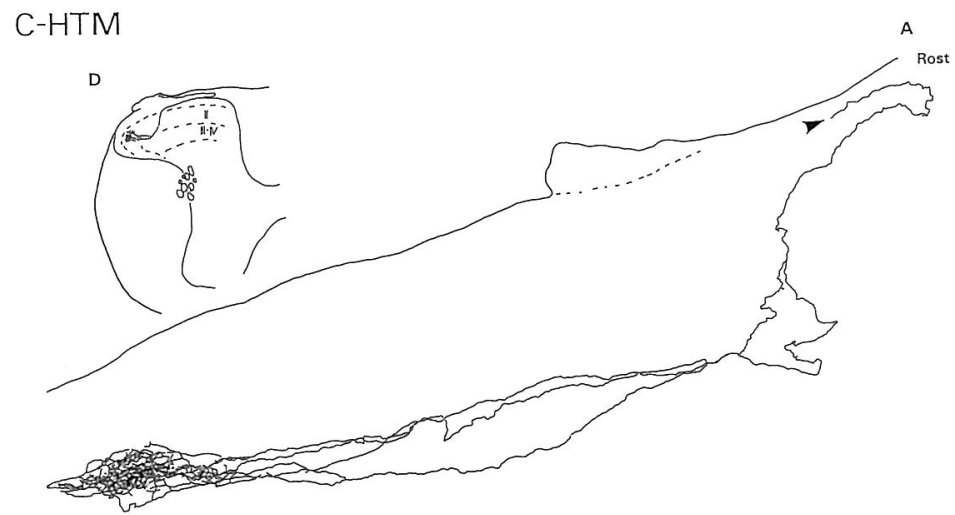

B

C

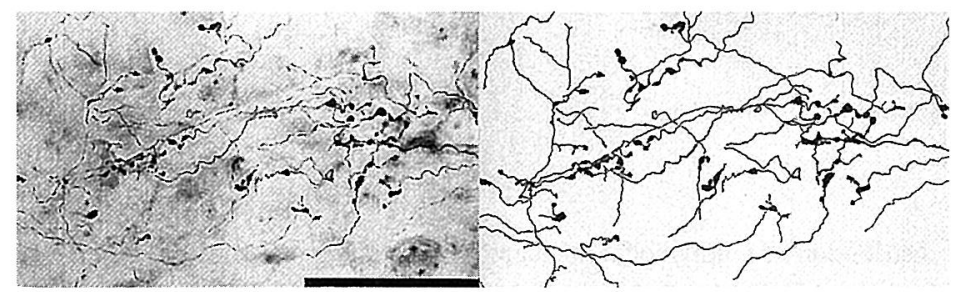

Fig. 1 A central trajectory of a high threshold mechanoreceptor of the C2 spinal cord. Receptive field was located in the center of the pinna. Conduction velocity was appproximately $0.5 \mathrm{~m} / \mathrm{sec}$. (A) Sagittal view of the reconstructed termination pattern in the serial sections by camera lucida. After enter the spinal cord, the fiber runs deeper layer and the terminates in the superficial layer (lamina II). A solid line indicates the outline of the dorsal surface of the spinal cord. An arrow head indicate the origin of the fiber from the rootlet. Scale; $100 \mu \mathrm{m}$. (B, C) Low magnification photomontage combined with different focused photographs and traced drawing, which shows terminal swellings in lamina II. Scale; $50 \mu \mathrm{m}$. (D) A transverse view of the fiber terminals. The fiber terminated in the lateral surface of the superficial dorsal horn.

\section{2. ポリモーダル侵害受容器 (PN)}

C2 後根神経節で記録した PN は耳介前方皮虞に強 い機械的刺激と熱刺激に反応する受容野を持ってい た. 後根神経枝は春髄後角に到達し Lissauer 路を後 方に約 $2000 \mu \mathrm{m}$ 走行し, 後角 II 層内層に密な終末分 枝を形成する．II層に形成される神経叢は吻尾方向 に約 $300 \mu \mathrm{m}$ で内外側に $200 \mu \mathrm{m}$ の領域に広がってい る. 終末膨大の大きさは $8 \mu \mathrm{m}$ に及ぶ (Fig. 2).

腰䯣 L6 後根神経節で記録したPN は後肢末梢の 第 3 足趾に受容野を持っていた. 終末分枝の走行は 頝䯣とは全く異なり，脊䯣表面に達すると吻尾方向 に分枝し，追跡できた長さは尾方の分枝が約 $1 \mathrm{~mm}$, 吻側の分枝は約 $3.5 \mathrm{~mm}$ であった。この神経は走行 途中 $200 〜 400 \mu \mathrm{m}$ 間隔で側枝を十数本出していた. 主な神経叢は数本の側枝から構成され，後根神経の 入った高さで吻尾方向に約 $600 \mu \mathrm{m}$, 内外側に $200 \mu \mathrm{m}$
の広がりを持ち, I 層と II 層の外層に集中していた. 側枝のほとんどは短く, 密な終末膨大をもたない. 側枝の中の 1 本のみが終末を III, IV 層に出してい た。終末膨大の大きさは最大長軸で $7.5 \mu \mathrm{m}$ に達し ていた (Fig. 3).

\section{3. 機械的寒冷侵害受容器 (MCN)}

C2 頚䯣から記録，標識された MCN は耳介前部の 皮虚に機械刺激と寒冷刺激に応じる受容野を持って いた．中枢枝は春䯣に入り，ほぼ 1 分節後方に走行 し，前，後に側枝を出す．前後の側枝はともに尙䯣 後角, 外側の I, II 層の境界領域で密な神経叢を作 り，終末領域を形成した.この終末領域は吻尾方向 に約 $400 \mu \mathrm{m}$ ，内外側に $150 \mu \mathrm{m}$ に展開していた。終 末膨大の大きさは約 $3.5 \mu \mathrm{m}$ 以下であった（Fig. 4). 一方，腰髄の $\mathrm{MCN}$ は春䯣に進入したレベルで密な 神経叢を形成し，吻尾方向で約 $450 \mu \mathrm{m}$, 内外側で 


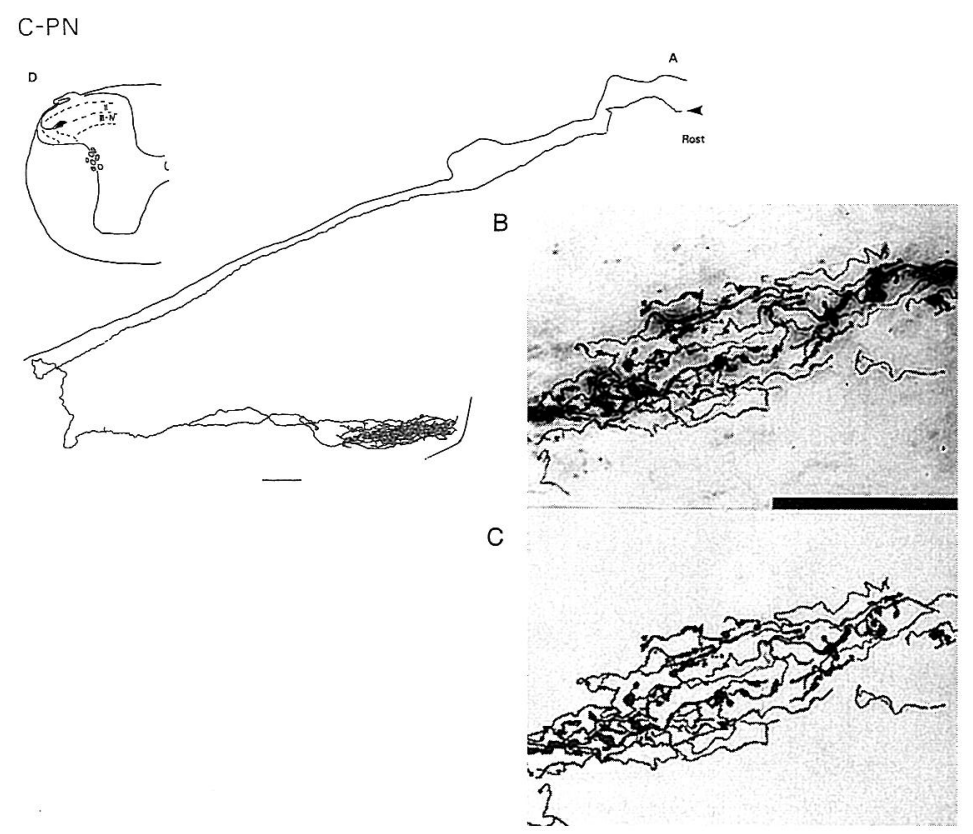

Fig. 2 The terminal distribution of a polymodal nociceptor in the $\mathrm{C} 2$ spinal cord. Receptive field was located in the anterior skin of the left pinna. (A) The sagittal view of the fiber was reconstructed by serial sections. Upon entering the spinal cord, the fiber runs caudally in Lissauer's tract about $2000 \mu \mathrm{m}$ and terminates in inner lamina II. Scale; $100 \mu \mathrm{m}$. (B, C) Photomontage of the fiber terminals and drawings traced from the same terminal field in Ili. The termination was constituted of concentrated terminal swellings which shows en passant or end terminals. Scale; $50 \mu \mathrm{m}$. (D) Transverse view of the fiber termination. Terminal plexus is located in inner lamina II after penetrating the lateral margin of the cervical spinal cord.
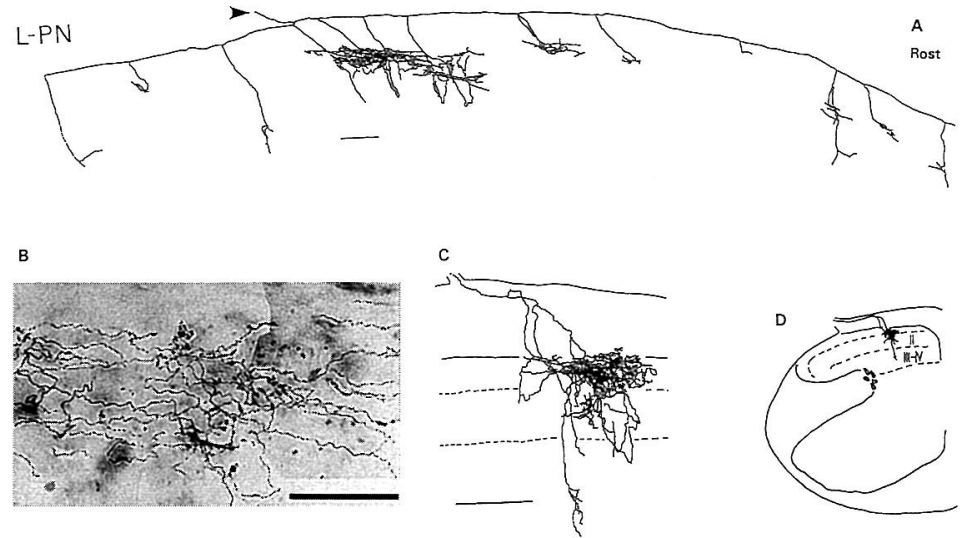

Fig. 3 Reconstructed views of a C polymodal nociceptor in the L6 spinal segment. Receptive field was located on the lateral skin of the third toe. (A) Sagittal view of the computer reconstructed termination pattern. Upon entering the spinal cord, the fiber bifurcated into a descending and an ascending branch. The descending branch was shorter (approximately $1080 \mu \mathrm{m}$ ) than the ascending (truncated by the rostral limit of the tissue block at $3550 \mu \mathrm{m}$ ). Most of the terminal arborization and boutons were located in laminae I and II. A few collaterals with small arborizations were found in laminae III and IV. Scale $200 \mu \mathrm{m}$. (B) Low magnification photomontage showing the labeled fiber and the terminal swellings in laminae I and II. Scale $50 \mu \mathrm{m}$. (C) Transverse view rotated by computer reconstruction. Most of the terminal arborizations were located in a narrow mediolateral sector of laminae I and II. Scale $200 \mu \mathrm{m}$. (D) Transverse drawing showing the terminal arborization of the fiber in relation to various laminae of the dorsal horn. 


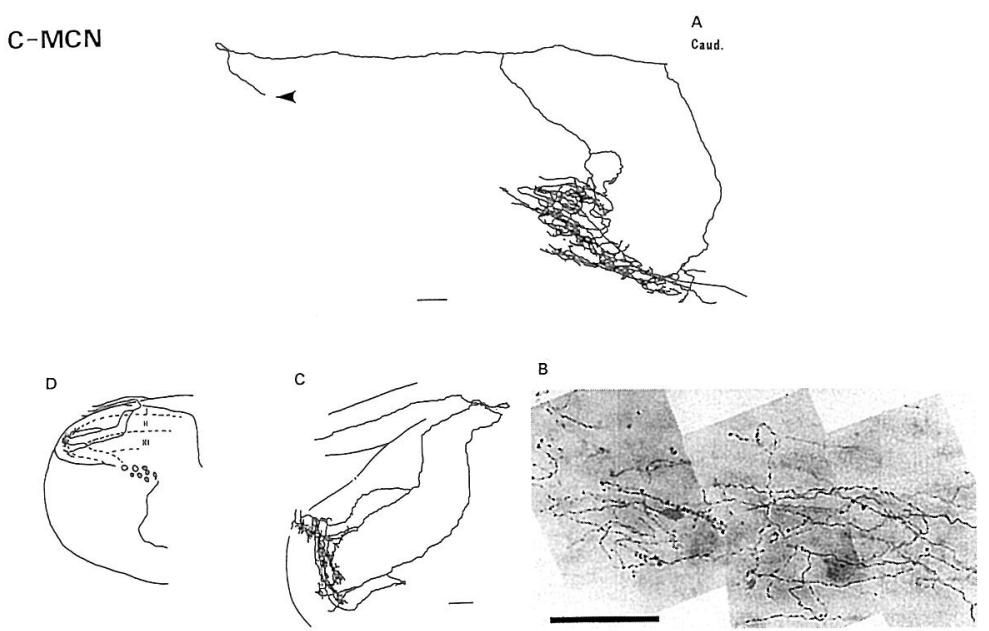

Fig. 4 Computer reconstruction of the central branches of a C-mechanical-cold nociceptor of the $\mathrm{C} 2$ segment using the three-dimensional interactive graphic program. The sagittal view of the fiber was reconstructed from 20 sagittal $50 \mu \mathrm{m}$ sections. The fiber ran caudally in Lissauer's tract to the $\mathrm{C} 3$ level, where several branches merged into a terminal plexus. The termination area extended to $400 \mu \mathrm{m}$ rostrocaudally and $150 \mu \mathrm{m}$ mediolaterally. An arrow head shows the point of entrance into the spinal cord. Scale; $100 \mu \mathrm{m}$. (B) Photomontage of the fiber termination in the superficial dorsal horn showing en passant and end-terminals of the fiber. Scale; $50 \mu \mathrm{m}$. (C) Transverse terminal profiles in lateral lamina I rotated by the computered graphic system. Scale; $100 \mu \mathrm{m}$. (D) Diagram showing arborization of the mechanical-cold nociceptor terminals in relatin to boundaries of the dorsal horn laminae.

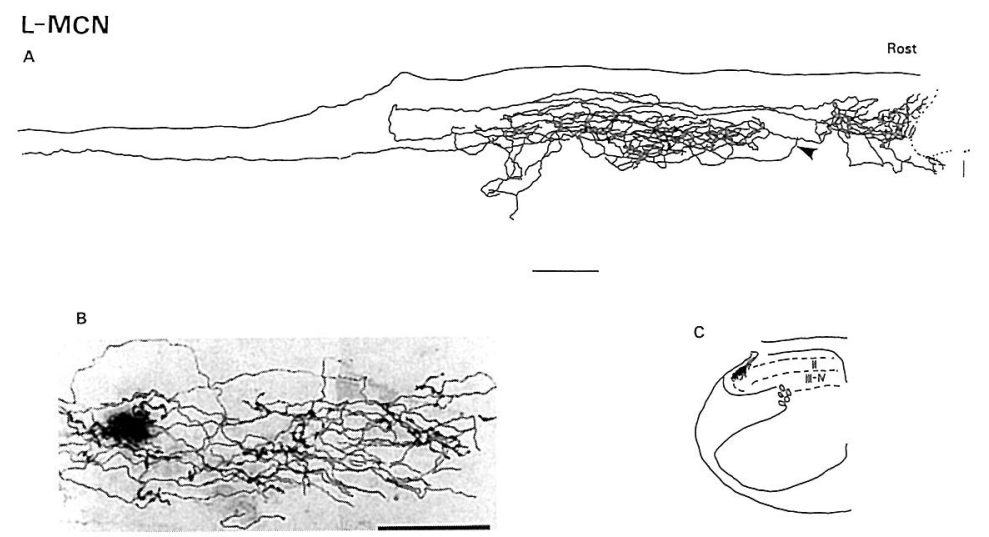

Fig. 5 A C-mechanical-cold nociceptor fiber in the L6 spinal cord. The receptive field was located on the backside thigh skin. (A) Sagittal reconstructed view of the fiber. A descending fiber runs in Lissauer's tract. Terminal arborization extended to $450 \mu \mathrm{m}$ rostrocaudally and $150 \mu \mathrm{m}$ mediolaterally. An arrowhead indicates the entry into the spinal cord. Scale; $100 \mu \mathrm{m}$. (B) Photomontage of the fiber and terminal swellings in the superficial dorsal horn (lamina I). Scale; $50 \mu \mathrm{m}$. (C) Transverse drawing of the MCN fiber which terminated at the border of laminae I and II of the dorsal horn.

$150 \mu \mathrm{m}$ の領域を持っていた。このように吻尾方向 に走る分枝を持つ腰䯣の終末像は有髄神経の終末分 布と類似している ${ }^{47,72)}$ 。この MCN の終末膨大の大 きさは $10 \mu \mathrm{m}$ に達するものもあった（Fig.5).

\section{4. 低閾值機械的受容器 (LTM)}

LTM は他の 2 つ侵害受容器と異なり無髄神経 の中で痛みの伝達に関与しない線維である.この受 容体は耳介外側皮䖉の軽いタッチに応じた。この LTM の中枢性終末は他の額髄の終末と同様に後方 
C-LTM

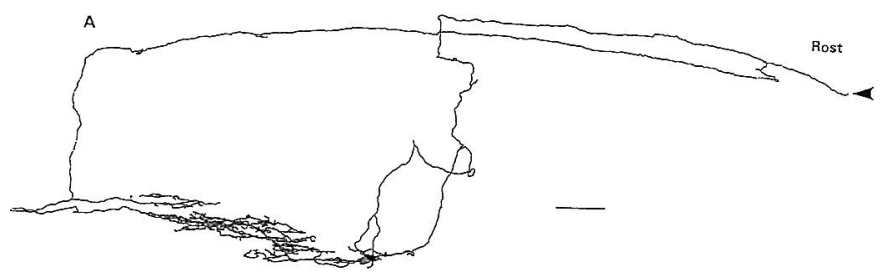

B
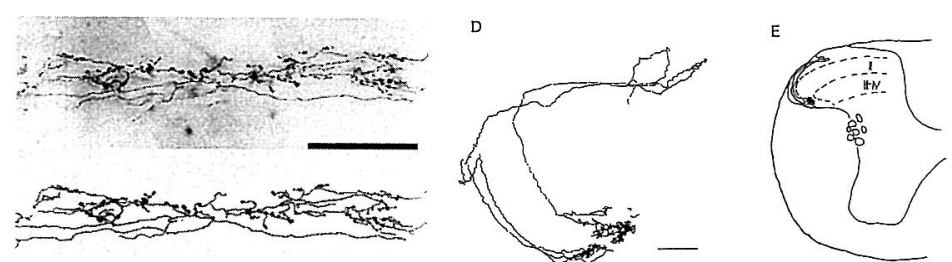

Fig. 6 Central projection of a C-low threshold mechanoreceptor in the $\mathrm{C} 2$ spinal segment. Receptive field located on lateral skin of pinna responsive to light touch. (A) Sagittal view of the computer reconstructed fiber based on 20 serial sections. The fiber runs caudally in Lissauer's tract and gives off several collaterals to terminate in the lateral part of lamina II. Terminal arborization reveals a narrow, long terminal band extending in $380 \mu \mathrm{m}$ rostrocaudally and $120 \mu \mathrm{m}$ mediolaterally. Scale; $100 \mu \mathrm{m}$. (B, C) Photomontage and traced drawing of the terminal arborization. Terminal swellings and end terminal branches were seen in the narrow terminal arborization. (D) Rotated transverse view of the computer reconstructed fiber. Several collaterals run the lateral margin of the dorsal horn and formed the narrow terminal arborization. (E) Transverse drawing of the fiber termination relative to the various laminae of the dorsal horn; The terminal arborization was located in the middle portion of lamina II in the lateral dorsal horn.

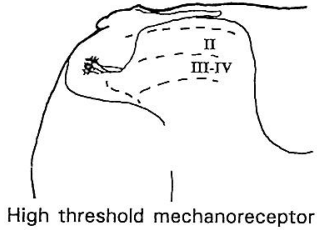
in cervical cord

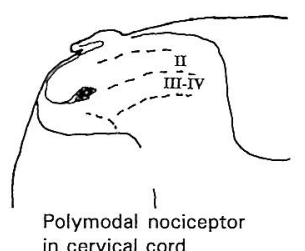
in cervical cord

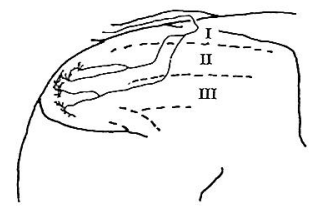

Mechanical cold nociceptor in cervical cord
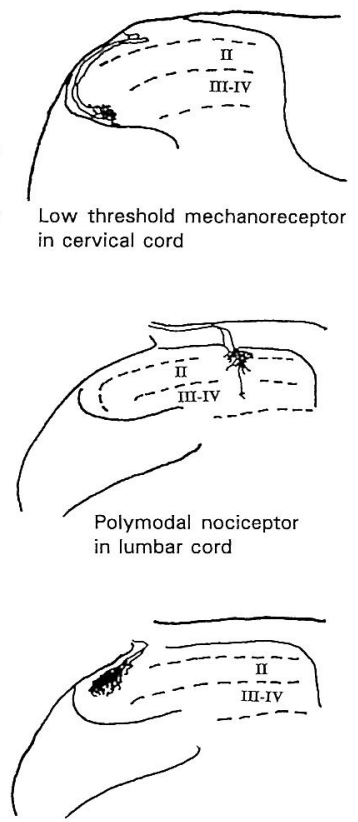

Mechanical cold nociceptor in lumbar cord
に走り後角外層縁に沿って 2 本の側枝を出す．最終 的にはすべての側枝は II 層の内層，外層の境界部に 棍棒上の長い神経叢を作っていた。この終末神経叢 の大きさは吻尾方向に $380 \mu \mathrm{m}$ ，内外側に $120 \mu \mathrm{m}$ で あった（Fig. 6).

いずれの感覚夕イプの受容器であれ $\mathrm{C} 2$ 後根神経 節の無䯣一次求心性神経の中枢終末は後方に走り, 脊髄の I, II 層を中心に終末していた。一方，腰㵦で の無髄神経終末は I, II 層に終末神経叢の領域を持つ が, 脊髄内での走行形態は末梢神経の分布域によっ て異なると思われた（Fig.7）。

Fig. 7 Schematic diagrams illustrating the location of physiologically identified unmyelinated fibers from the skin. The transverse plane drawings were reconstructed from distribution observed in parasagittal histological sections of the cervical or the lumbar spinal cord. 


\section{8}
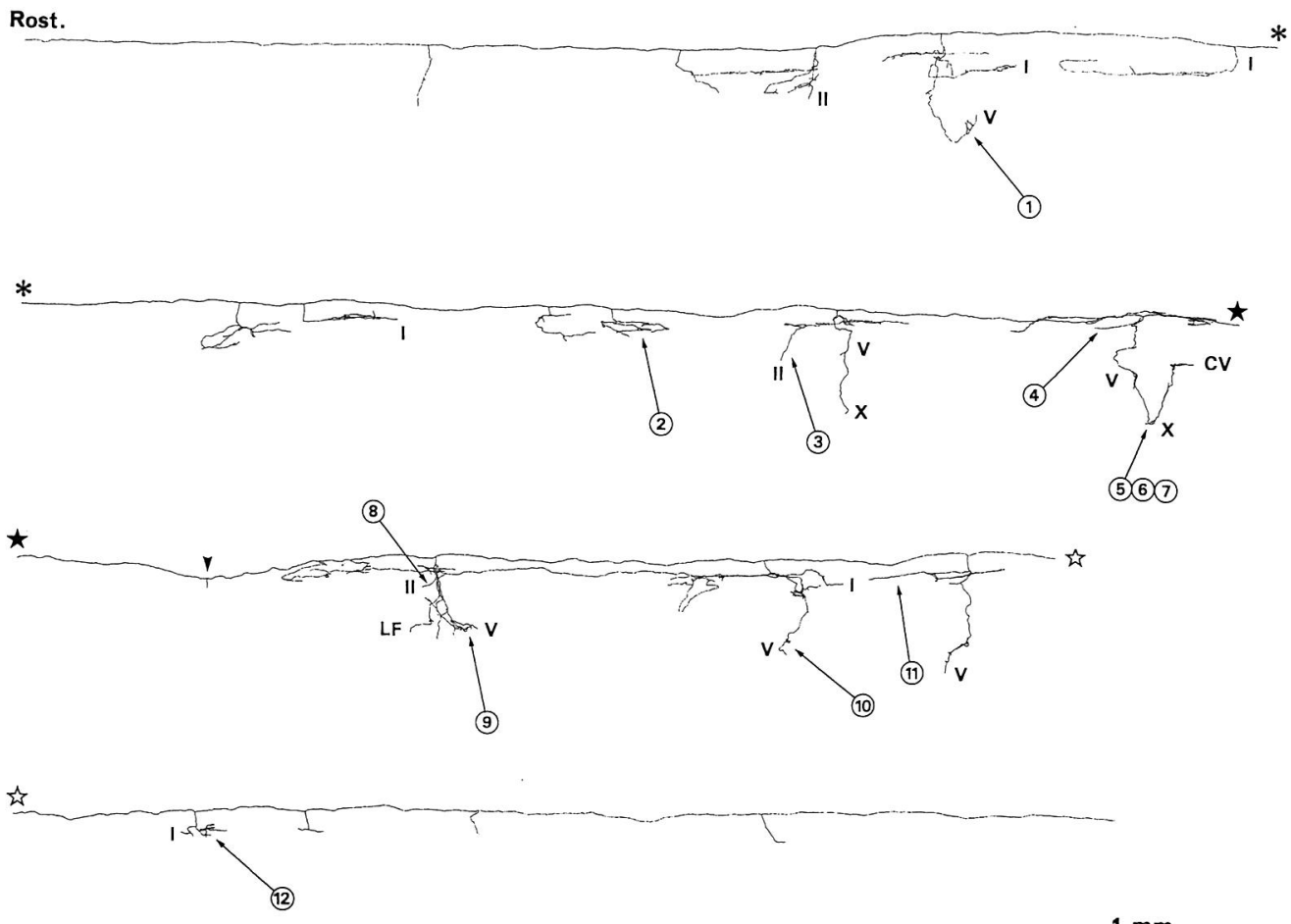

$1 \mathrm{~mm}$

Fig. 8 Sagittal view of the reconstructed projection of a visceral afferent C-fiber. The outline of central arborization of the fibers are shown in the camera lucida drawing. On entering the spinal cord (arrowhead in third from the top segment), the axon bifurcates into ascending and descending main branches. The main ascending and descending branches run on the dorsal surface of the spinal cord or Lissauer's tract as far rostrally as the 10th thoracic segment (top left) and as far caudally as the second lumbar (bottom right) segment. Many collaterals leave these parent branches to terminate in laminae I, and II. Some collaterals also terminate in the lateral funiculus and ipsilateral or contralateral laminae V and X. Black stars, open stars and asterisks indicate where the illustrations are interrupted. Circle number indicate the terminal branches drawn in Figure 9 as representative terminals from each layer. LF, Lateral funiclus; V, ipsilateral lamina V; CV, contralateral lamina V; X, ipsilateral lamina $\mathrm{X}$.

\section{内臓からの無䯑道求心性神経終末}

内臓からの無䯣神経終末は腹腔神経節近傍の神経 の電気刺激により, Th13 後根神経節で細胞内活動 電位を得て記録し，標識した。その他の方法は皮虞 での記録と同様である。無髄の内歲求心性神経は, 電気刺激部位と細胞記録をした Th13 後根神経節と の直接距離が短いにもかかわらず，スパイクの伝導 時間がかなり延長するものがみられた。これはおそ らく一次求心性神経が経由する交感神経節の数, 線
維の入る交感神経節のレベルによると考えられた。

骨盤内臓求心性線維を HRP で染色した所見では 脊䯣後角の内側，外側を通り終末している $26,42,43$, 55,56)．単一神経で記録した無髄内臓求心性神経の沓 髄終末の分枝は，皮虚などからの体性無髄神経が集 中した神経叢を形成するのに対して，全く違った神 経分布をしている. 求心性線維は後根から春髄に入 り，吻側枝と尾側枝に分岐し，およそ数分節にわた り上行，下行する。そしてその間に 20 本近い側枝 を脊䯣の I, II, IV, V, X 層, 側索，反対側の $\mathrm{V}, \mathrm{X}$ 層 


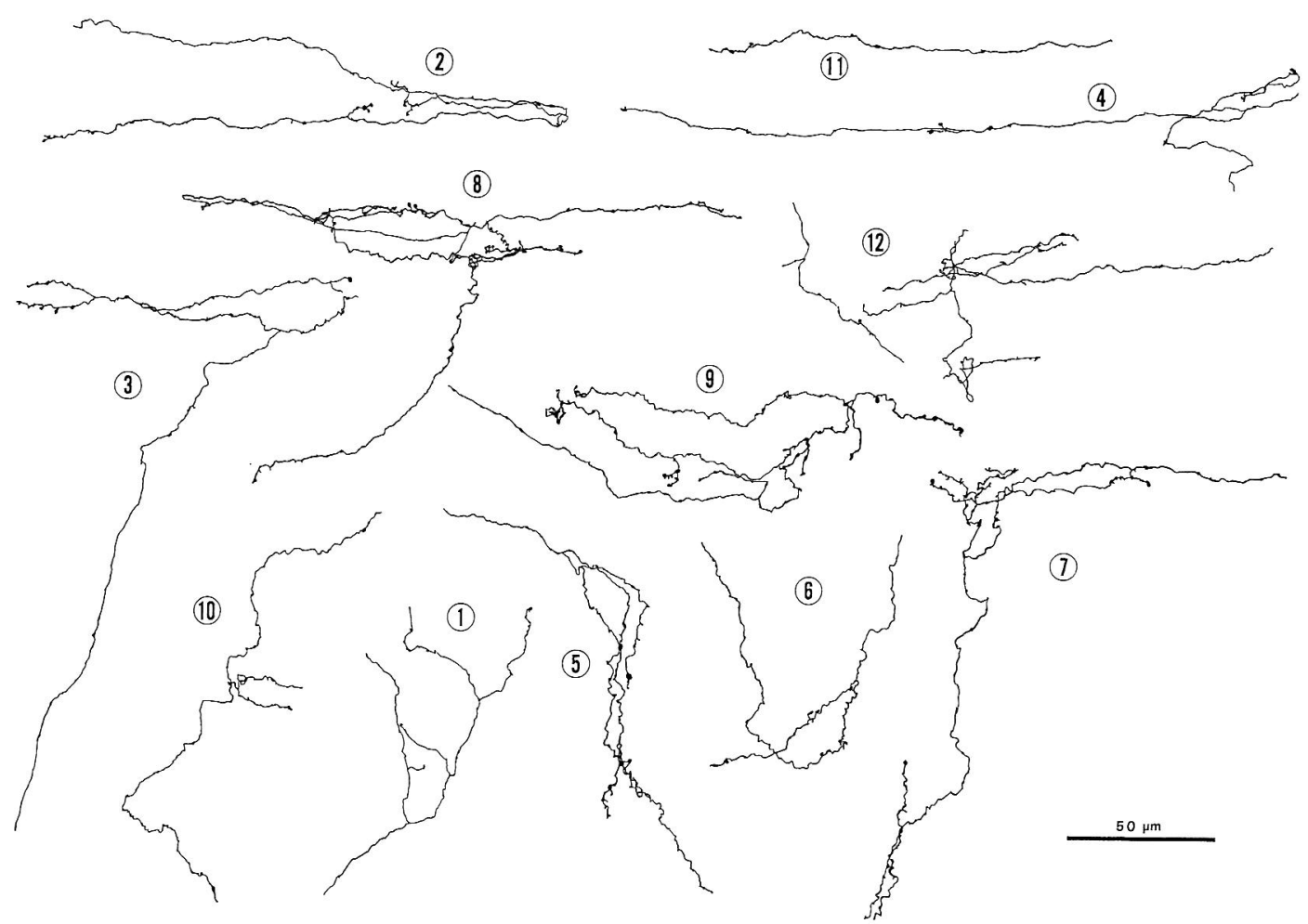

Fig. 9 Terminal branches from the visceral afferent C-fiber of Figure 8 drawn in parasagittal sections at high magnification. The circled numerals correspond to those in Figure 8. Number 2, 4, 11, and a part of 12 are in lamina I; parts of 3 , 8 are in lamina II; 1, 5, 9 and 10 are in lamina V; 7 is in contralateral lamina V; and 6 is in lamina X. The array of terminal branches is arranged with orientation to the neuropil.

に終末する 54,91）（Fig. 8)。終末分枝は神経叢を作ら ず，比較的単純で真っ直ぐな終末分布で 1 分枝支配 領域は狭い92）（Fig. 9).

\section{筋からの無髄（C または Group IV）求心性線維}

筋からの無髄求心性線維は後肢腓腹筋の外側頭の 支配神経を電気刺激し, L5 後根神経節で細胞内工 ニット電気記録を行い，伝導速度により無䯣神経で あることを確認した．筋からの無髄神経の中には神 経終末が尾側から吻側に後索表層を数分節にわたり 走行するものもあった．神経終末は主に I, II, III 層 に終末しており，終末膨大の密度がそれほど高くな い神経叢を形成していた．神経叢は全終末分布領域 の中に $1 \sim 2$ 力所に存在し, その領域の広がりは吻 尾方向に $200 \sim 600 \mu \mathrm{m}$, 内外側に $200 \sim 300 \mu \mathrm{m}$ で あった，終末膨大は比較的小さく，大きさは最大 $2 \sim 3 \mu \mathrm{m}$ であった，腓腹筋 C 線維 (group IV) の腰
髄での分節の広がりは他の HRP の注入実験の結果 と同じであるが51,77)，春髄後角における分布は明 らかに異なり表層 I, II, III 層に限られていた。

\section{無髄神経の定量的比較}

体性神経, 内臓神経, 筋神経の 3 種類の無髄神経 の定量的検討として, 終末分布領域にある終末膨大 の数で比較してみると, 体性神経は主に I, II 層に神 経趣を形成し，1 終末領域に約 $700 〜 1500$ 個の終末 膨大を数えた。一方内臓神経は I, II 層に体性神経の 約 3 倍の $2500 \sim 4000$ 個の終末膨大を数えるが，終 末分枝の数が多く, 1 神経終末領域は $200 \sim 300$ 個 の終末膨大を持つにすぎない（Table 2)．筋神経で は I, II 層にある終末膨大は $1500 ３ 000$ 個の終末膨 大を数えるが，神経叢の数は 2 ～ 3 領域にすぎない のでその数は 1 領域 500 ～ 1000 個に相当する 38,39 ) (Table 3). 
Table 2 Number of terminal swellings of visceral and somatic fibers

\begin{tabular}{lcccc} 
& \multicolumn{2}{c}{ Visceral fibers } & \multicolumn{2}{c}{ Somatic fibers } \\
Case Number & 10588 & 30488 & 70887 & 72987 \\
Numberl of swellings & $6099(100)$ & $5370(100)$ & 1482 & 1450 \\
Number of terminal area & 22 & 18 & 1 & 2 \\
Mean number of area & 277 & 298 & -- & 725 \\
Dorsal funiculus & $359(5.9)$ & $1089(20.3)$ & & \\
Lamina I & $3735(61.2)$ & $2466(45.9)$ & & \\
lamina II & $240(3.9)$ & $151(2.8)$ & & \\
lamina IV and V & $391(6.1)$ & $553(10.3)$ & & \\
lateral funiculus & $276(4.5)$ & $21(0.4)$ & & \\
Lamina X & $171(2.8)$ & $153(2.8)$ & & \\
Contralateral X & $121(2.0)$ & $61(1.1)$ & & \\
Contralateral IV and V & $108(1.8)$ & $142(2.6)$ & & \\
Total number(\%) & $5401(88.6)$ & $4636(86.3)$ &
\end{tabular}

Table 3 Number of terminal swellings of C-fibers from the gatrocunemius muscle

$\begin{array}{lrcr}\text { Case Number } & 010201 & 010206 & 010327 \\ \text { Drosal funiclus } & 3261 & 1068 & 1660 \\ \text { I abd II } & 1393 & 2395 & 2874 \\ \text { III } & 53 & & 180 \\ \text { Number of terminal area } & 3 & 2 & 3 \\ \text { Total number } & 4670 & 3463 & 4714\end{array}$

また吻尾方向の領域の広がりをみると内臓神経は 数分節， $20 \mathrm{~mm}$ にも及ぶが，体性神経はほとんど数 百ミクロンに展開するのみである．筋肉からの無髄 神経は数分節にわたるものから数百ミクロンに分布 するものまで様々であった.

体性無髄神経の春髄終末の分布領域, すなわち吻 尾方向に数百ミクロン, 内外側に 200 ミクロンとい う広がりは後角膠様質の神経細胞の広がりと警くほ ど一致している ${ }^{80,89)}$. 内臓神経の側枝の分布が数 百ミクロン間隔であるということは，交感神経の節 前神経節細胞の梯子状構造の間隔とほぼ一致してい る32,33,57,60,61,63 65,78). また分枝における終末膨大 の密度の低さは，内臓感覚あるいは関連痛の局在性 のなさ, 曖昧さの形態学的背景となるものかもしれ ない 10,18,21,22,27,49,59,62,79,81). 腓腹筋の C 線維 (group IV）の分節の広がりと春髄後角における分布は，C 線維の伝える感覚，あるいは末梢受容器の存在する 組織の違いを表しているのかもしれない50).

現在，痛みの解析が分子レベルで進んでゆく中で も，痛みの原因を見つけ，理解する上では，機能形 態学的背景は不可欠なものである.この分野でのさ らに詳細な研究が期待される。

\section{文献}

1) Abrahams, V.C., Richmond, F.J. and Keane, J., Projections from $\mathrm{C} 2$ and $\mathrm{C} 3$ nerves supplying muscle and skin of the cat neck: A study using transganglionic transport of horseradish peroxidase, J. Comp. Neurol., 230 (1984) 142-154.

2) Abrahams, V.C. and Swett, J.E., The pattern of spinal and medullary projections from a cutaneous nerve and muscle nerve of the forelimb of the cat: A study using the transganglionic transport of HRP, J. Comp. Neurol., 246 (1986) 70-84.

3) Alvarez, F.J., Kavookjian A.M. and Light, A.R., Ultrastructural morphology, synaptic relationships, and CGRP immunoreactivitiy of physiolgically identified C-fiber terminals in the monkey spinal cord, $J$. Comp. Neuol., 329 (1993) 472-490.

4) Arvidsson, J. and Pfaller, K., Central projections of C4-C8 dorsal root ganglia in the rat studied by anterograde transport of WGA-HRP, J. Comp. Neurol., 292 (1990) 349-362.

5) Arvidsson, J. and Rice, F.L., Central projections of primary sensory neurons innervating different parts of the vibrissae follicles and intervibrissal skin on the mystacial pad of the rat, J. Comp. Neurol., 309 (1991) 1-16.

6) Basbaum, A.I., Cruz, L. and Weber, E., Immunoreactive dynorphin $\mathrm{B}$ in sacral primary afferent fibers 
of the cat, J. Neurosci., 6 (1986) 127-133.

7) Beal, J.A. and Bicknell, H.R., Primary afferent distribution pattern in the marginal zone (lamina I) of adult monkey and cat lumbosacral spinal cord, J. Comp. Neurol., 202 (1981) 255-263.

8) Bessou, P. and Perl, E.R., Response of cutaneous sensory units with unmyelinated fibers to noxious stimuli, J. Neurophysiol., 32 (1969) 1025-1043.

9) Bessou, P., Burgess, P.R., Perl E.R. and Taylor, C.B., Dynamic properties of mechanoreceptors with unmyelinated (C) fibers, J. Neurophysiol., 34 (1971) 116-131.

10) Brown, A.G., Organization in the spinal cord. The anatomy and physiology of identified neurones, Springer-Verlag, New York, 1981, pp1-238.

11) Brown, A.G., Fyffe, R.E.W. and Noble, R., Projections from pacinian corpuscles and rapidly adapting mechanoreceptors of glabrous skin to the cat's spinal cord, J. Physiol., 307 (1980) 385-400.

12) Brown, P.B., Gladfelter, W.E., Culberson, J.C., Covalt-Dunning, D., Sonty, R.V., Pubols, L.M. and Millecchia, R.J., Somatotopic organization of single primary afferent axon projections to cat spinal cord dorsal horn, J. Neurosci., 11 (1991) 298-309.

13) Brown, A.G., Rose, P.K. and Snow, P.J., Morphology and organization of axon collaterals from afferent fibres of slowly adapting type I units in cat spinal cord, J. Physiol., 277 (1978) 15-27.

14) Capra, N. F. and Wax, T. D., Distribution and central projections of primary afferent neurons that innervate the masseter muscle and mandibular periodontium: A double-label study, J. Comp. Neurol., 279 (1989) 341-352.

15) Carson, K.A. and Mesulam, M.-M., Ultrastructural evidence in mice that transganglionically transported horseradish peroxidase-wheat germ agglutinin conjugate reaches the intraspinal terminations of sensory neurons, Neurosci. Lett., 29 (1982) 201-206.

16) Castro-Lopes, J. M. and Coimbra, A., Spinal cord projections of the rat main forelimb nerves, studies by transganglionic transport of WGA-HRP and by the disappearance of acid phosphatase, Brain Res., 542 (1991) 187-192.

17) Cervero, F., Somatic and visceral inputs to the thoracic spinal cord of the cat: effects of noxious stimulation of the biliary system, J. Physiol., 337 (1983) 51-67.

18) Cervero, F., Sensory innervation of the viscera: Peripheral basis of visceral pain, Physiol. Rev., 74 (1994) 95-138.

19) Cervero, F. and Connell, L.A., Fine afferent fibers from viscera do not terminate in the substantia gelatinosa of the thoracic spinal cord, Brain Res., 294 (1984a) 370-374.

20) Cervero, F. and Connell, L.A., Distribution of somatic and visceral primary afferent fibers within the thoracic spinal cord of the cat, J. Comp. Neurol., 230 (1984b) 88-98.

21) Cervero, F. and Lumb, B.M., Bilateral inputs and supraspinal control of viscero-somatic neurones in the lower thoracic spinal cord of the cat, J. Physiol., 403 (1988) 221-237.

22) Cervero, F. and Tattersall, J.E.H., Somatic and visceral inputs to the thoracic spinal cord of the cat: Marginal zone (Lamina I) of the dorsal horn, J. Physiol., 383 (1987) 383-395.

23) Conradi, S., Cullheim, S., Gollvik, L. and Kellerth, J.-O., Electron microscopic observations on the synaptic contacts of group Ia muscle spindle afferents in the cat lumbosacral spinal cord, Brain Res., 265 (1983) 31-39.

24) Craig, A.D. and Mense, S., The distribution of afferent fibers from the gastrocnemius-soleus muscle in the dorsal horn of the cat, as revealed by the transport of horseradish peroxidase, Neurosci. Lett., 41 (1983) 233-238.

25) Cruz, F., Lima, D., Zieglgänsberger, W. and Coimbra A., Fine structure and synaptic architecture of HRPlabelled primary afferent terminations in lamina IIi of the rat dorsal horn, J. Comp. Neruol., 305 (1991) 316.

26) de Groat, W.C., Nadelhaft, I., Morgan, C. and Schauble, T., Horseradish peroxidase tracing of visceral efferent and primary afferent pathways in the cat's sacral spinal cord using benzidine processing, Neurosci. Lett., 10 (1978) 103-108.

27) Fields, H.L., Meyer, G.A. and Partridge, L.D., Convergence of visceral and somatic input onto spinal neurons, Exp. Neurol., 26 (1970) 36-52.

28) Fyffe, R.E.W. Afferent fibers. In R.A. Davidoff (Ed.), Handbook of the spinal cord, Marcel Dekker, New York, 1984, pp79-136.

29) Gerfen, C.R. and Sawchenko, P.E., An antcrograde neuroanatomical tracing method that shows the detailed morphology of neurons, their axons and terminals: Immunohistochemical localization of an axonally transported plant lectin, phaseolus vulgaris leucoagglutinin (PHA-L), Brain Res., 290 (1984) 219-238.

30) Gobel, S. Fall, W.M. and Humphrey E., Morphology and synaptic connections of ultrafine primary axon in lamina I of the spinal dorsal horn: candidates for the terminal axonal arbors of primary neurons with unmyelinated (C) axons, J. Neurosci., 1 (1981) 1163- 
1179.

31) Hammond, D.L. and Ruda, M.A., Developmental alterations in nociceptive threshold, immunoreactive calcitonin gene-related peptide and substance $\mathrm{P}$, and fluoride-resistant acid phosphatase in neonatally capsaicin-treated rats, J. Comp. Neurol., 312 (1991) 436-450.

32) Hancock, M.B. and Peveto, C.A., A preganglionic autonomic nucleus in the dorsal gray commissure of the lumbar spinal cord of the rat, J. Comp. Neurol., 183 (1979) 65-72.

33) Honda, C.N., Visceral and somatic afferent convergence onto neurons near the central canal in the sacral spinal cord of the cat, J. Neurophysiol., 53 (1985) 1059-1078.

34) Honda, T., Ozaki, N., Tonosaki, Y., Nishiyama, K., Shigemoto, R. and Sugiura Y., Synaptic organization and ultrasuructural features of the substance Preceptor-like immunoreactive neurons in the nucleus intemediolatellis of rats, Neurosci. Lett., 197 (1995) 117-120.

35) Hongo, T., Kudo, N., Sasaki, S., Yamashita, M., Yoshida, K., Ishizuka, N. and Mannen, H., Trajectory of group Ia and Ib fibers from the hind-limb muscle at the L3 and L4 segments of the spinal cord of the cat, J. Comp. Neurol., 262 (1987) 159-194.

36) Ishizuka, N., Mannen, H., Hongo, T. and Sasaki, S., Trajectory of group Ia afferent fibers stained with horseradish peroxidase in the lumbosacral spinal cord of the cat: Three dimensional reconstructions from serial sections, J. Comp. Neurol., 186 (1979) 189-212.

37) Jankowska, E., Rastad, J. and Westman, J., Intracellular application of horseradish peroxidase and its light and electron microscopical appearance in spinocervical tract cells, Brain Res., 105 (1976) 557562.

38) Koerber, H.R. and Mendell, L.M., Functional specialization of central projections from identified primary afferent fibers, J. Neurophysiol., 60 (1988) 1597-1614.

39) Koerber, H.R., Brown, P.B. and Mendell, L.M., Correlation of monosynaptic field potentials evoked by single action potentials in single primary afferent axons and their bouton distributions in the dorsal horn, J. Comp. Neurol., 294 (1990) 133-144.

40) Kumazawa, T. and Perl, E.R., Primate cutaneous sensory units with unmyelinated (C) afferent fibers, J. Neurophysiol., 40 (1977) 1325-1338.

41) Kumazawa, T. and Perl, E.R., Excitation of marginal and substantia gelatinosa neurons in the primate spinal cord: indications of their place in dorsal horn functional organization, J. Comp. Neruol., 162 (1978) $1-12$.

42) Kuo, D.C. and de Groat, W.C., Primary afferent projections of the major splanchnic nerve to the spinal cord and gracile nucleus of the cat, J. Comp. Neurol., 231 (1985) 421-434.

43) Kuo, D.C., Nadelhaft, I., Hisamitsu, T. and de Groat W.C., Segmental distribution and central projections of renal afferent fibers in the cat studied by transganglionic transport of horseradish peroxidase. $J$. Comp. Neurol., 216 (1983) 162-174.

44) LaMotte, C.C., Distribution of the tract of Lissauer and the dorsal root fibers in the primate spinal cord, J. Comp. Neurol., 172 (1977) 529-562.

45) LaMotte, C.C. and Campbell, J.N., Comparison of responses of warm and nociceptive $\mathrm{C}$-fiber afferents in monkey with human judgment of thermal pain, $J$. Neurophysiol., 41 (1978) 509-528.

46) Light, A.R. and Perl, E.R., Reexamination of the dorsal root projection to the spinal dorsal horn including observations on the differential termination of coarse and fine fibers, J. Comp. Neurol., 186 (1979a) 117-132.

47) Light, A.R. and Perl, E.R., Spinal termination of functionally identified primary afferent neurons with slowly conducting myelinated fibers, J. Comp. Neurol., 186 (1979b) 133-150.

48) Lynn B. and Carpenter, S.E., Primary afferent units from the hair skin of the rat hind limb, Brain Res., 238 (1982) 29-43.

49) Mei, N., Sensory structure in viscera, Prog. Sensory Physiol., 4 (1983) 1-42.

50) Mense, S., Structure-function relationships in identified afferent neurones. Anat. Embryol., 181 (1990) 117.

51) Mense, S and Craig, A.D., Spinal and supraspinal terminations of primary afferent fibers from the gastrocnemius-soleus muscle in the cat, Neuroscience, 26 (3) (1988) 1023-1035.

52) Mense, S. and Prabhakar, N. R., Spinal termination of nociceptive afferent fibres from deep tissues in the cat, Neurosci. Lett., 66 (1986) 169-174.

53) Merighi, A., Kar, S., Gibson, S.L., Ghidella, S., Gobetto, A., Peirone, S.M. and Polak, J.M., The immunocytochemical distribution of seven peptides in the spinal cord and dorsal root ganglia of horse and pig, Anat. Embryol., 181 (1990) 271-280.

54) Mizumura, K., Sugiura, Y. and Kumazawa, T., Spinal termination patterns of canine identified A- and C spermatic polymodal receptors traced by intracellular labeling with Phaseolus vulgaris-Leucoagglutinin, $J$. 
Comp. Neurol., 335 (1993) 460-468.

55) Morgan, C., Nadelhaft, I. and de Groat W.C., The distribution of visceral primary afferents from the pelvic nerve to Lissauer's tract and spinal gray matter and its relationship to the sacral parasympathetic nucleus, J. Comp. Neurol., 201 (1981) 415-440.

56) Morgan, C., de Groat, W. C. and Nadelhaft, I., The spinal distribution of sympathetic preganglionic and visceral primary afferent neurons that send axons into the hypogastric nerves of the cat, J. Comp. Neurol., 243 (1986) 23-40.

57) Nadelhaft, I., Poppolo, J., Morgan C. and de Groat, W.C., Parasympathetic preganglionic neurons and visceral primary afferents in monkey sacral spinal cord revealed following application of horseradish peroxidase to pelvic nerve, J. Comp. Neurol., 216 (1983) 36-52.

58) Nagy, J.I., Hunt, S.P., Iverson, L.L. and Emerson, P.C., Biochemical and anatomical observations on the degeneration of peptide containing primary afferent neurons after neonatal capsaicin, Neurosci., 6 (1981) 1923-1934

59) Ness, T.J. and Gebhart, G.F., Characterization of neuronal responses to noxious visceral and somatic stimuli in the medial lumbosacral spinal cord of the rat, J. Neurophysiol., 57 (1987) 1867-1892.

60) Ness, T.J. and Gebhart, G.F., Visceral pain: a review of experimental studies, Pain, 41 (1990) 167-234.

61) Ness, T.J. and Gebhart, G.F., Interactions between visceral and cutaneous nociception in the rat. I. Noxious cutaneous stimuli inhibit visceral nociceptive neurons and reflexes, J. Neurophysiol., 66 (1991a) 20-28.

62) Ness, T.J. and Gebhart, G.F., Interactions between visceral and cutaneous nociception in the rat. II. Noxious visceral stimuli inhibit cutaneous nociceptive neurons and reflexes, J. Neurophysiol., 66 (1991b) 29-39.

63) Núñez, R., Gross, G.H. and Sachs B.D., Origin and central projections of rat dorsal penile nerve: Possible direct projection to autonomic and somatic neurons by primary afferents of nonmuscle origin, J. Comp. Neurol., 247 (1986) 417-429.

64) Oldfiels, B.J. and McLachlan, E.M., An analysis of the sympathetic preganglionic neurons projecting from the upper thoracic spinal roots of the cat, $J$. Comp. Neurol., 196 (1981) 329-345.

65) Petras, J.M. and Cummings, J.F., Autonomic neurons in the spinal cord of the rhesus monkey: A correlation of the findings of cytoarchitectonics and sympathectomy with fiber degeneration following dorsal rhizo- tomy, J. Comp. Neurol., 146 (1972) 189-218.

66) Pfaller, K., and Arvidsson, J., Central distribution of trigeminal and upper cervical primary afferents in the rat studied by anterograde transport of horseradish peroxidase conjugated to wheat germ agglutinin, $J$. Comp. Neurol., 268 (1988) 91-108.

67) Priestley, J.V., Somogyi, P. and Cuello, A.C., Immunocytochemical localization of substance $P$ in the spinal trigeminal nucleus of the rat: A light and electron microscopic study, J. Comp. Neurol., 211 (1982) 31-49.

68) Prihoda, M., Hiller, M-S. and Mayr, R., Central projections of cervical primary afferent fibers in the guinea pig: An HRP and WGA/HRP tracer study, $J$. Comp. Neurol., 308 (1991) 418-431.

69) Ralston, H.J., The fine structure of neurons in the dorsal horn of the cat spinal cord, J. Comp. Neurol., 132 (1968a) 275-302.

70) Ralston, H.J., Dorsal root projections to dorsal horn neurons in the cat spinal cord, J. Comp. Neurol., 132 (1968b) 303-330.

71) Ralston, H.J., The fine structure of laminae I, II and III of the Macaque spinal cord, J. Comp. Neurol., 184 (1979) 619-642.

72) Réthelyi, M., Preterminal and terminal axon arborizations in the substantia gelatinosa of cat's spinal cord, J. Comp. Nerurol., 172 (1977) 511-527.

73) Réthelyi, M., Light, A.R. and Perl, E.R., Synaptic complexes formed by functionally defined primary afferent units with fine myelinated fibers, J. Comp. Neurol., 207 (1982) 381-393.

74) Rexed, B., The cytoarchitectonic organization of the spinal cord in the cat, J. Comp. Neurol., 96 (1952) 415-495.

75) Ribero-da-Silva, A. and Coimbra, A., Two types of synaptic glomeruli and their distribution in laminae IIII of the rat spinal cord, J. Comp. Neurol., 209 (1982) 176-186.

76) Ritz, L.A., Brown, P.B. and Bailey, S.M., Crossed and uncrossed projections to cat sacrocaudal spinal cord: I. Axons from cutaneous receptors, J. Comp. Neurol., 289 (1989) 284-293.

77) Ritz, L.A., Bailey, S.M., Carter, R.L., Sparkes, M.L., Masson, R.L. and Rohoton, E.L., Crossed and uncrossed projections to cat sacrocaudal spinal cord: II, Axons from muscle spindles primary endings, $J$. Comp. Neurol., 304 (1991) 316-332.

78) Rubin, E. and Purves, D., Segmental organization of sympathetic preganglionic neurons in the mammalian spinal cord, J. Comp. Neurol., 192 (1980) 163-174.

79) Ruch, T.C., Visceral sensation and referred pain. In 
J.F. Fulton (Ed.), A textbook of physiology, Saunders, Philadelphia, 1949, pp360-374.

80) Scheibel, M.E. and Scheibel, A.B., Terminal axonal patterns in the cat spinal cord. II. The dorsal horn, Brain Res., 9 (1968) 32-58.

81) Selzer, M. and Spencer, W.A., Convergence of visceral and cutaneous afferent pathways in the lumbar spinal cord, Brain Res., 14 (1969) 331-348.

82) Semba, K., Masarachia, P., Malamed, S., Jacquin, M., Harris, S., Yang, G. and Egger, M.D., An electron microscopic study of primary afferent terminals from slowly adapting type I receptors in the cat, J. Comp. Neurol., 221 (1983) 466-481.

83) Semba, K., Masarachia, P., Malamed, S., Jacquin, M., Harris, S. and Egger, M., Ultrastructure of Pacinian corpuscle primary afferent terminals in the cat spinal cord, Brain Res., 302 (1984) 135-150.

84) Semba, K., Masarachia, P., Malamed, S., Jacquin, M., Harris, S., Yang, G. and Egger, M.D., An electron microscopic study of terminals of rapidly adapting mechanoreceptive afferent fibers in the cat spinal cord, J. Comp. Neurol., 232 (1985) 229-240.

85) Shea, V.K. and Perl, E.R., Sensory receptors with unmyelinated (C) fibers innervating the skin of the rabbit's ear, J. Neurophyiol., 54 (1985) 491-501.

86) Shigenaga, Y., Otani, K. and Suemune S. Morphology of central terminations of low-threshold trigeminal primary afferents from facial skin in the cat-intra-axonal staining with HRP, Brain Res., 523 (1990) 23-50.

87) Shortland, P., Woolf, C.J. and Fizgerald, M., Morphology and somatotopic organization of the central terminals of hindlimb hair follicle afferents in the rat lumbar spinalcord, J. Comp. Neurol., 289 (1989) 416-433.

88) Snow, P.J., Rose, P.K. and Brown, A.G., Tracing axons and axon collaterals of spinal neurons using intracellular injection of horseradish peroxidase, Science, 191 (1976) 312-313.

89) Sugiura, Y., Three dimensional analysis of neurons in the substantia gelatinosa Rolandi, Proc. Jpn. Acad., 51 (1975) 336-341.

90) Sugiura, Y., Lee, C.L. and Perl, E.R., Central projections of identified, unmyelinated (C) afferent fibers innervating mammalian skin, Science, 234 (1986) 358-361.

91) Sugiura, Y., Terui, N. and Hosoya, Y., Difference in distribution of central terminals between visceral and somatic unmyelinated (C) primary afferent fibers, $J$. Neurophysiol., 62 (1989) 834-840.

92) Sugiura, Y. Terui, N., Hosoya, Y., Tonosaki, Y., NIshiyama, K. and Honda, T., Quantitative analysis of central terminal projections of visceral and somatic unmyelinated $(\mathrm{C})$ primary afferent fibers in the guinea pig, J. Comp. Neurol., 332 (1993) 315-325.

93) Sugiura, Y and Tonosaki, Y., Spinal organization of unmyelinated visceral afferent fibers in comparison with somatic afferent fibers. In G.F. Gebhart (Ed.), Visceral Pain, Prog. In Pain Res. and Manag., Vol.5, IASP Press, Seattle, 1995.

94) Szentágothai, J., Neuronal and synaptic arrangement in the substantia gelatinosa Rolandi, J. Comp. Neurol., 122 (1964) 219-239.

95) Woolf, C.J., Central terminations of cutaneous mechanoreceptive afferents in the rat lumbar spinal cord, J. Comp. Neurol., 261 (1987) 105-119.

96) Woolf, C.J. and Fitzgerald, M., The properties of neurones recorded in the superficial dorsal horn of the rat spinal cord, J. Comp. Neurol., 251 (1983) 517 531.

97) Ygge, J. and Grant, G., The organization of the thoracic spinal nerve projection in the rat dorsal horn demonstrated with transganglionic transport of horseradish peroxidase, J. Comp. Neurol., 216 (1983) 1-9.

Address for correspondence: Yasuo Sugiura, M.D.

Department of Functional Anatomy and Neuroscience

Nagoya University Graduate School \& Faculty of Medicine

65 Tsurumaimi-cho, Showa-ku, Nagoya 466-8550, Japan

Tel: 052-744-2016 Fax: 052-744-2025

E-mail: ysugiura@med.nagoya-u.ac.jp 